\title{
Transcriptional and Epigenetic Regulation of Neural Crest Induction during Neurulation
}

\author{
Chandra S. Mayanil \\ Developmental Biology Program, Lurie Children's Hospital of Chicago Research Center, Division of Pediatric \\ Neurosurgery, Northwestern University Feinberg School of Medicine, Chicago, III., USA
}

\section{Key Words}

Epigenetics · Chromatin remodeling · Folic acid · Gene regulation · microRNA - Neural crest · Neural stem cell · Neural tube $\cdot$ Neurulation

\begin{abstract}
Neurulation is one of the many important events in mammalian development. It is the stage of organogenesis in vertebrate embryos during which the neural tube is transformed into the primitive structures that will later develop into the central nervous system. Recent transcriptome analysis during neurulation and early organogenesis in humans and mice has identified the global dynamics of gene expression changes across developmental time. This has revealed a richer understanding of gene regulation and provides hints at the transcriptional regulatory networks that underlie these processes. Similarly, epigenome analysis, which collectively constitutes histone modifications, transcription factor binding, and other structural features associated with gene regulation, has given a renewed appreciation to the subtle mechanisms involving the process of neurulation. More specifically, the histone demethylases KDM4A and KDM6B have recently been shown to be key histone H3K4 and H3K27 modifiers that regulate neural crest specification and neural tube closure. Additionally, miRNAs have recently been
\end{abstract}

shown to influence transcription of genes directly or by altering the levels of epigenetic modifiers and thus regulate gene expression. This mini review briefly summarizes the literature, highlighting the transcriptional and epigenetic regulation of key genes involved in neural crest induction and neural crest specification by transcription factors and miRNAs. Understanding how these mechanisms work individually and in clusters will shed light on pathways in the context of diseases associated with neural crest cell derivatives such as melanoma, cardiovascular defects and neuronal craniofacial defects.

(c) 2013 S. Karger AG, Basel

\section{Introduction}

In vertebrates, the neural tube is the embryo's precursor to the central nervous system, which comprises the brain and spinal cord. Neurulation is the stage of organogenesis in vertebrate embryos during which the neural tube is transformed into the primitive structures that will later develop into the central nervous system [1]. This stage consists of primary and secondary neurulation. Primary neurulation divides the ectoderm into the following cell types: (a) the neural tube (internally located); (b) the epidermis (externally located), and (c) neural crest cells 
(NCCs). NCCs develop in the region between the neural tube and epidermis, and as development progresses migrate to new locations. Primary neurulation begins after the neural plate forms. The edges of the neural plate start to thicken and lift upward, forming the neural folds. The center of the neural plate remains grounded, allowing a $\mathrm{U}$-shaped neural groove to form. This neural groove sets the boundary between the right and left sides of the embryo. The neural folds pinch in towards the midline of the embryo and fuse together to form the neural tube [2]. Figure 1 depicts all the processes and some of the important genes/proteins involved at different stages of the induction of neural crest (NC). In secondary neurulation, the cells of the neural plate form a cord-like structure that migrates inside the embryo and hollows to form the tube. Neural tubes in mammals close in the head in the opposite order than they close in the trunk. In the head (a) NCCs migrate; (b) the neural tube closes, and (c) the overlying ectoderm closes. In the trunk (a) the overlying ectoderm closes; (b) the neural tube closes, and (c) NCCs migrate [2].

The notochord plays an integral role in the development of the neural tube. The notochord induces the neural tube to form in the overlying ectoderm. This is known as primary induction. Once the ectoderm is induced to become neural ectoderm, it can also induce its neighbors to become neural ectoderm. This is called planar induction. The ectoderm is divided into three major domains: the surface ectoderm, which generates primarily epidermis; the neural tube, which generates brain and spinal cord, and the NC generating peripheral neurons, pigment and facial cartilage $[2,3]$. The dorsal neural tube creates the NCCs, which migrate away following an epithelial-tomesenchymal conversion to give rise to a diverse set of cell types. These include peripheral nervous system, adrenal medulla, melanocytes, facial cartilage and dentine of teeth. The peripheral nervous system consists of Schwann cells, neuroglial cells, sympathetic nervous system and parasympathetic nervous system, sympathetic ganglia, dorsal root sensory ganglia and melanocytes of the skin [4]. Neurulation creates the outer ectodermal layer, which covers over the neural tube once it is created. The ectodermal layer gives rise to epidermis, hair, nails, sebaceous glands, olfactory epithelium, mouth epitheli$\mathrm{um}$, lens and cornea. The mouth epithelium gives rise to anterior pituitary, tooth enamel and cheek epithelium [5]. At the end of crest emigration, the midline of the dorsal neural tube becomes the roof plate. This serves as a signaling center for the organization of dorsal neuronal cell types [6].

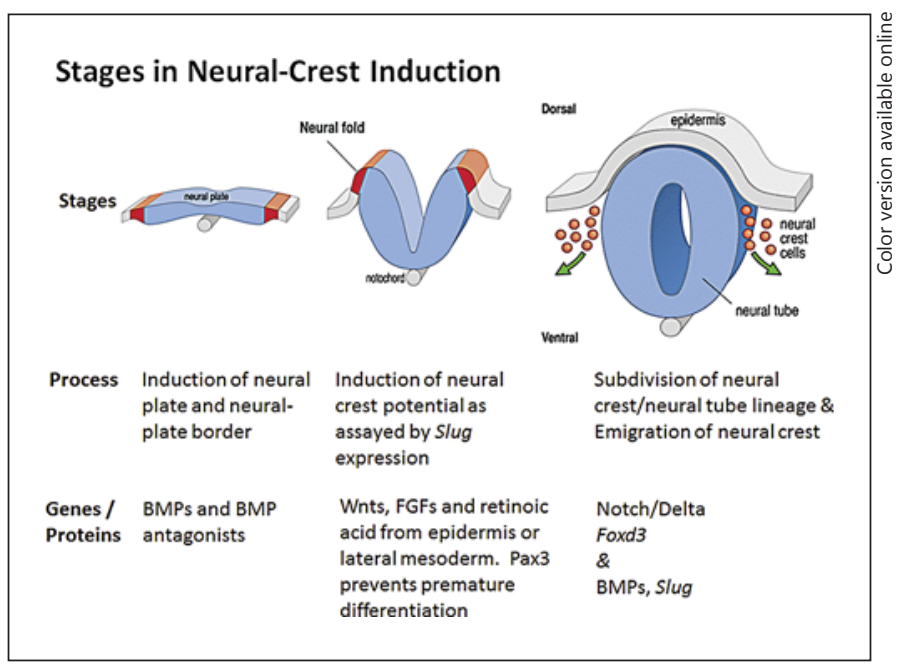

Fig. 1. A model describing different stages in NC induction. The process begins with induction of the neural plate and its border, mediated, in part, by inhibition of BMP signaling by members of the TGF $\beta$ family (for example noggin). This border region acquires the potential to form $\mathrm{NC}$ as a result of additional signaling (by Wnts, FGFs or retinoic acid) from the epidermis, paraxial mesoderm or both. NC potential must then be maintained, perhaps through the activity of BMPs in the dorsal neural tube. Multipotent precursors proliferate in response to Wnt1 and Wnt3a, but are prevented from differentiating prematurely by Pax3. Eventually, these precursors adopt the fate of either NC or dorsal neurons in a process that involves Notch/Delta signaling and Foxd3. Finally, BMPs and Slug are again important as NCCs emigrate from the neural tube.

In mammals, miRNAs, noncoding RNAs approximately 22 nucleotides in length, play critical roles in various physiological processes by acting as posttranscriptional regulators to reduce translation of target genes by either destabilizing mRNAs or blocking their translation $[7,8]$. miRNAs are central regulators of NC development [9-11].

In the NC, repression of targets by regional and spatiotemporal biogenesis of miRNAs elicits critical changes in gene expression programs that regulate gene regulatory networks crucial to NC development [12]. Knowledge of miRNA expression profiles during NCC differentiation into distinct lineages introduces the possibility of producing adult NC stem cells (NCSCs) for regenerative purposes. This mini review briefly summarizes the literature, highlighting the transcriptional and epigenetic regulation of key genes involved in NC induction and NC specification. This understanding will shed light on pathways linked to neurocristopathies or diseases associated with NCC derivatives such as melanoma, cardiovascular defects and neuronal craniofacial defects. 
Fig. 2. NC induction and neural plate border specification. BMP, Wnt and FGFs are neural induction signals. The Wnt from mesoderm, and FGF from mesoderm and non-neural ectoderm with varying levels of $\mathrm{BMP}$, trigger the expression of neural plate border specifier genes, such as Pax3, Zic1, $G b \times 2, D l \times 3 / 5$ and $M s \times 1 / 2$. Pax3 and Zic1 in the presence of Wnt upregulate Snail and FoxD3 expression, respectively. MiRNAs that regulate other genes or are regulated by gene products are listed in the red boxes. The $\rightarrow$ denote activation and $\perp$ denote suppression. MiRNAs are listed in boxes with red frames (black frames in the print version); genes are designated by squares or ovals.

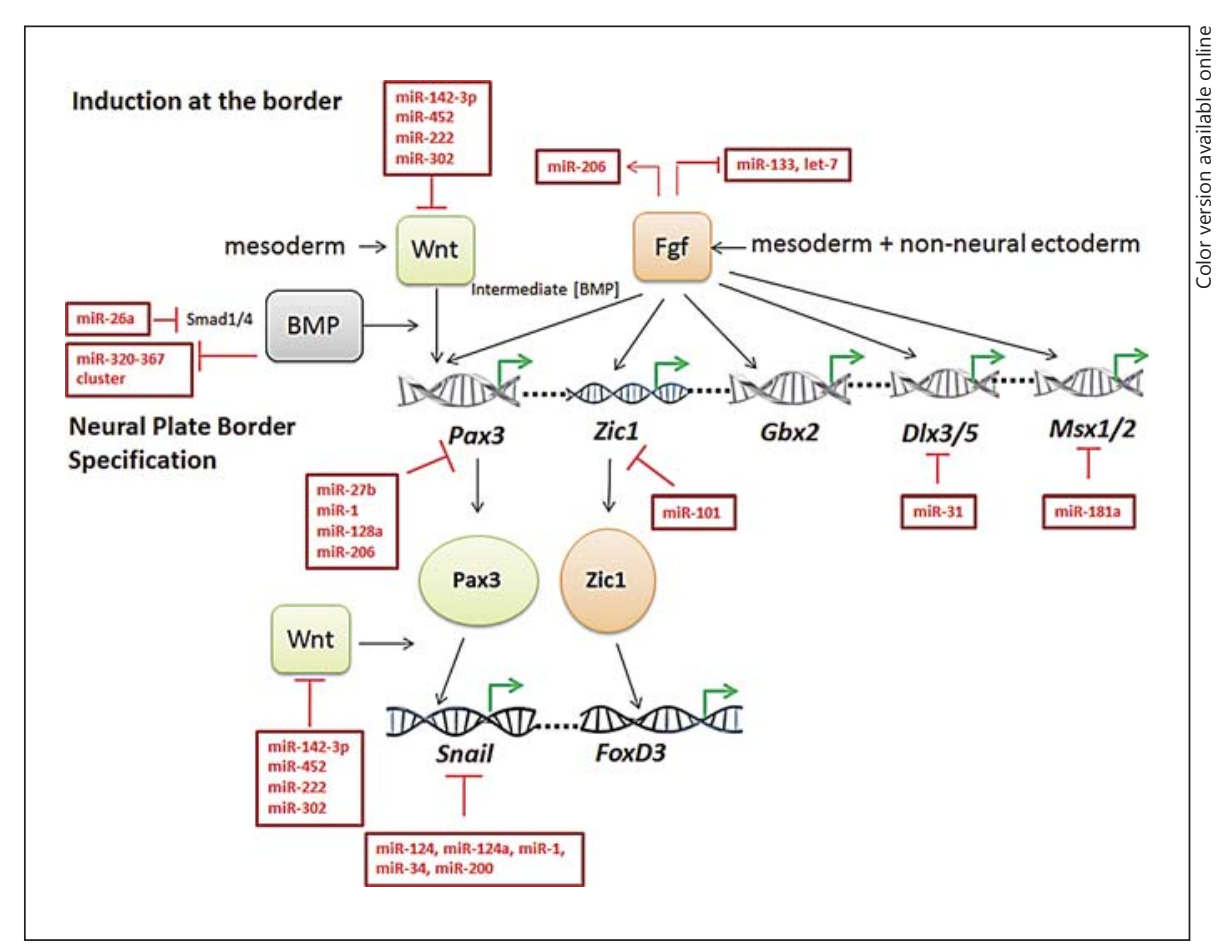

\section{NC Induction: Transcriptional Regulation of Genes}

NCCs arise in the neural folds at the border between neural and non-neural ectoderm in early embryos [13]. Neural induction is defined as the step when ectodermal cells become specified as neural stem or precursor cells. Later in development, these specified cells will no longer respond to signals that induce alternative fates, and have thus committed to a neural fate. Ultimately, these cells will differentiate into neurons and other neural cell derivatives [14]. NC induction occurs via signaling between these tissues and appears to be mediated by the Wnt and BMP signaling pathways $[15,16]$. NC induction at the plate border is mediated by mesodermal signals which include fibroblast growth factor (FGF) and mesodermal and adjacent non-neural ectodermal Wnt signaling. One or both of these signals induce expression of individual neural plate border specifiers, such as Pax 3 and Zic1, in a manner that is dependent on intermediate levels of BMP $[15,16] . G b \times 2, D l \times 3 / 5$ and $M s \times 1 / 2$ are also unregulated; Pax3 and Zic1 in turn upregulate NC specifiers (fig. 2) in neural folds and/or dorsal neural tube. Neural plate border specification is brought about by neural plate border specifier genes such as Zic1, Msx1, Msx2, Dlx3, Dlx5, Pax3, Pax7, Snail1 and AP-2. Pax3 and Zic1 are independently regulated [17]; however, they act synergistically in a Wnt-dependent manner to activate NC specifiers such as Snail2 and FoxD3. An appropriate balance of Zic1 and Pax3 is required to induce the NC (fig. 2). For reviews of neural border specifiers and early NC crest markers, see Milet and Monsoro-Burq [15, 16] and Betancur et al. [18].

$\mathrm{NC}$ specification is defined by the expression of $\mathrm{NC}$ specifier genes in premigratory and NC progenitors. NC specification involves three important events: (1) delamination; (2) epithelial-to-mesenchymal transformation (EMT), and (3) NC cell fate determination and differentiation (fig. 3).

\section{Delamination}

NCCs separate from neighboring neuroepithelial cells by delamination, which involves a partial or complete EMT [19]. At delamination, the tissue splits into separate populations. Delamination is triggered by a Bmp/canonical Wnt cascade involving Bmp4, Wnt1, Msx1 and cMyb [20,21], which promotes EMT via activation of Snail2, Foxd3 and members of the SoxE family [22]. Snail2, Foxd3, Sox9 and Sox 10 activate $\beta 1$-integrin [22], participate in switching cadherin profiles from $\mathrm{N}$-cadherin to cadherin $6 \mathrm{~B}$ to cadherin 7 and 11 [23], and modulate RhoB expression [24]. The switch from strong cell adhesion (mediated by $\mathrm{N}$-cadherin) required for maintaining epithelial integrity to weak cell-cell adhesion 
Fig. 3. A summary of gene regulatory networks and miRNAs in NC specification. a-c NC specification involves processes that give the neural plate border progenitor characteristics of the bona fide NC. These cells undergo EMT, cell cycle arrest followed by delamination, extensive migration and different events of terminal differentiation. MiRNAs that regulate other genes or are regulated by gene products that are involved in cell cycle/delamination, EMT and NCC differentiation are shown. The $\rightarrow$ denote activation and $\perp$ denote suppression. miRNAs are listed in boxes with red frames (thick black frames in the print version); genes are designated by squares or ovals.

\section{NC Specification}

a

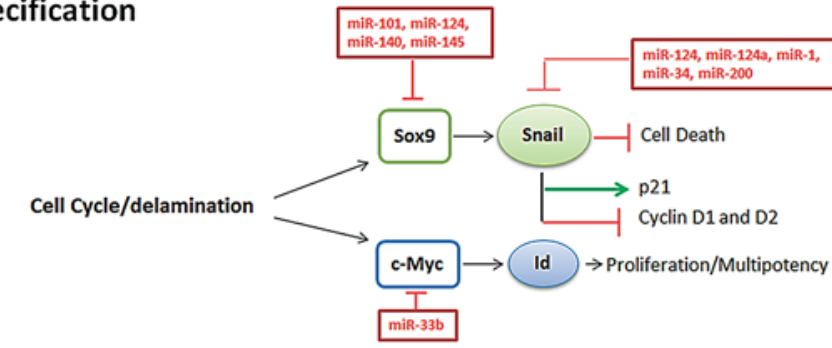

Cell Cycle/delamination

b

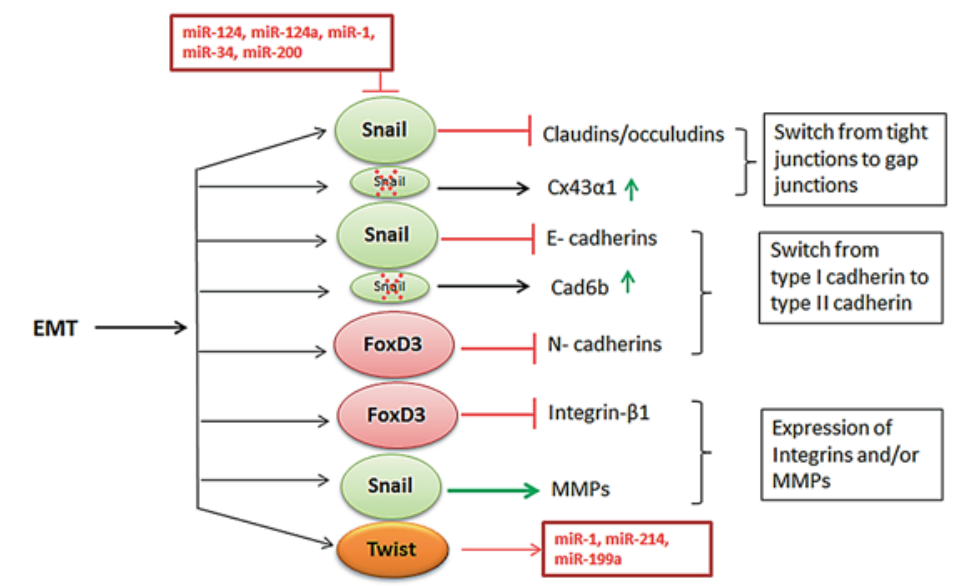

C
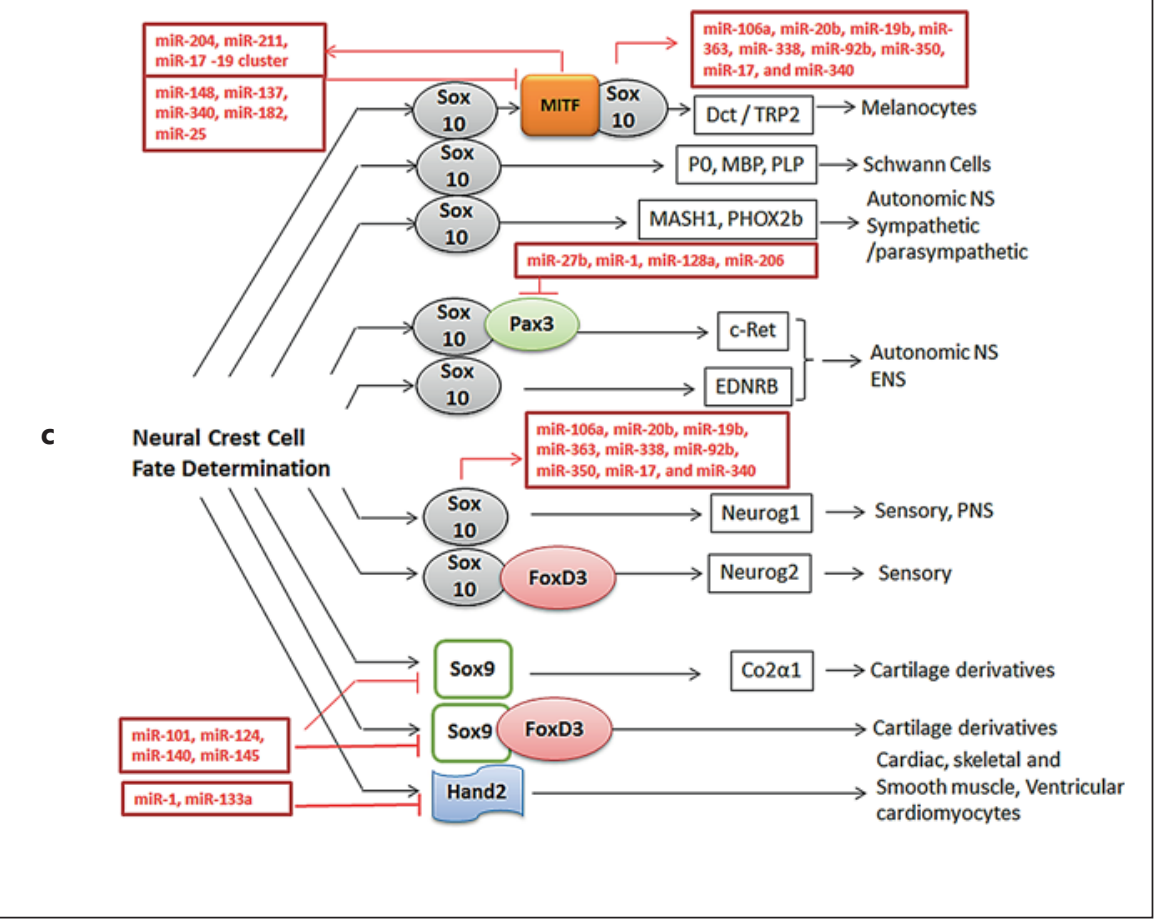
(supported by cadherin 6B and cadherin 7) promoting separation from the epithelium and allowing cell migration may be a general step during NC development. The $\mathrm{BMP} 4 / \mathrm{Wnt} 1$ cascade is also essential for the G1/S transition of NC precursors located in the dorsal neural tube [20], to maintain NC identity [22]. Activation of the $\mathrm{BMP} / \mathrm{Wnt}$ cascade is linked to somite maturation and noggin inhibition which leads to early departure of NC cells, while maintenance of noggin blocks NC delamination [25]. Differentiating somites appear to release a factor that blocks noggin expression in the dorsal neural tube [26]. This unidentified factor in turn initiates the $\mathrm{BMP} / \mathrm{Wnt}$ cascade. Taken together, the data indicate that a combination of factors, including ligands and transcription factors, is required to promote NCC delamination.

\section{Epithelial-to-Mesenchymal Transformation}

EMT is a series of events at the molecular level orchestrating a change from an epithelial to a mesenchymal phenotype [27]. EMT is brought about by the integration of extracellular signals, which include extracellular matrix components such as collagen or hyaluronic acid, and secreted ligands, such as members of the TGF $\beta$ and FGF families. These receptor-mediated signaling events [28] in turn upregulate the expression of Snail1, Snail2 and FoxD3 that orchestrates cellular changes by directly mediating transitions in cell-junction assembly, motility and adhesion occurring during EMT [29, 30].

For EMT to occur, premigratory NCCs which exist within a fully polarized epithelial layer, adjoined by adherens junctions and tight junctions, have to lose their apical-basal cell polarity and dissolve tight junctions. These events are accompanied by changes in cytoskeletal organization and a switch in adhesive properties so that cells can separate from the neuroepithelium and emigrate [28]. Cadherins play a major role in EMT. Type I cadherins, associated with stable cell assemblies, are replaced by mesenchymal cell type II cadherins, with lower adhesiveness, allowing NC cells to increase their motility [31]. NC specifiers FoxD3 and Snail downregulate expression of $\mathrm{N}$-Cad and E-Cad (or Cad6B in chick and mouse), respectively, while upregulating mesenchymal migratory proteins, such as Cad7. Similarly, Snail downregulates tight junction claudins/occludins and upregulates the gap junction protein connexin-43a1 (Cx43a1) [18].

\section{NCC Fate Determination/Differentiation}

After separating from surrounding tissue, NCCs migrate extensively throughout the embryo. To arrive at their target region, NCCs must interpret multiple envi-

Transcriptional and Epigenetic Regulation of NC Induction ronmental signals that directly influence where they go and settle to differentiate $[32,33]$. SoxE transcription factors Sox 9 and Sox 10 are major players in this process. These transcription factors regulate effector genes that give derivative cells their terminal characteristics. Sox 9 is first expressed during NC specification in premigratory NCCs and Sox 10 during early delaminating and migrating NCCs. These transcription factors later control the differentiation of NC-derived cartilage by directly binding the collagen type II $\alpha 1$ (Col2 $\alpha 1)$ promoter [34]. Sox10 expression persists in neurons and melanocytes, regulating multiple downstream effectors [35]. Sox10 (1) regulates $[36,37]$ and also acts synergistically with MITF to control the expression of dopachrome tautomerase (Dct/ TRP2) [36], essential for melanin synthesis during melanocyte differentiation; (2) controls the expression of both Mash 1 and Phox $2 b$, two key transcription factors responsible for sympathetic neuron fate [38]; (3) regulates neurogenin-1 (Neurog1) [35] and therefore regulates sensory neuron fate specification also; (4) in the enteric nervous system, Sox10 controls the glial-cell-derived neurotrophic factor (GDNF)-Ret pathway by physically interacting with PAX3 to synergistically activate the c-Ret receptor tyrosine kinase that transduces GDNF signals $[39,40]$ in the enteric nervous system; (5) during gliogenesis, SOX10 directly regulates Schwann cell-specific myelin genes such as protein zero $(\mathrm{P} 0)$, myelin basic protein (MBP), proteolipid protein [41], connexin-32, connexin-47 and peripheral NS myelin [42], and (6) coordinates normal enteric NS development in collaboration with endothelin-3 [43].

\section{Epigenetic Regulation of Genes Involved in NC Induction}

\section{MicroRNAs in Caudal Neural Tube}

There has been minimal work done on the role of miRNAs in caudal neural tube development. miRNAs act as modulators of the epigenetic landscape in NCSCs [44]. MicroRNAs regulate molecules that change histone marks during NC development. MicroRNA genes can be epigenetically regulated and miRNAs can in turn repress key enzymes that drive epigenetic remodeling. Ichi et al. [45], using a folate-responsive mouse model of neural tube defect, Splotch, showed that in heterozygous mouse embryos, levels of miRNAs such as miR-138, miR-148a, miR-185 and miR-339-5p were upregulated. These miRNAs target KDM6B, a histone H3K27 demethylase, thus decreasing KDM6B expression and increasing 
H3K27 methylation. This in turn altered methylation patterns on Hes1 promoter, associated with stem cell maintenance and proliferation, and Neurog 2 promoter, associated with sensory differentiation, compared to wild-type embryos. Methylated H3K27 associates with the Hes 1 promoter and methylation results in decreased Hes 1 expression and lowered stem cell proliferation. Simultaneously, low association between methylated $\mathrm{H} 3 \mathrm{~K} 27$ and the Neurog2 promoter, but high association between acetylated $\mathrm{H} 3 \mathrm{~K} 9$ and $\mathrm{H} 3 \mathrm{~K} 18$ and the Neurog 2 promoter, results in premature neurogenesis. Folic acid-mediated rescue of the caudal neural tube phenotype in Splotch could be due to reversible downregulation of KDM6B targeting miRNAs, resulting in upregulation of KDM6B and subsequent lowering of H3K27 methylation [45]. Demethylated H3K27 showed decreased binding with Hes1 promoter and increased binding with Neurog 2 promoter, resulting in increased stem cell proliferation/maintenance and normal neurogenesis instead of premature neurogenesis [39]. The reason why this happens is not clear. Demethylated H3K27 could possibly render the chromatin more open for normal neurogenesis. Demethylated H3K27 occupancy with Neurog2 promoter could make the acetylated histone such as H3K9 or H3K18 more accessible to the Neurog2 promoter, resulting in normal neurogenesis. In short, folic acid can regulate expression of these miRNAs and therefore modulate the epigenetic landscape of Hes 1 and Neurog2 during neural tube closure [45]. Other miRNAs that regulate epigenetic targets such as EZH2, HDAC1/4 and DNMT1 are shown in table 1.

\section{MicroRNAs in Cranial NC}

Cranial NCCs make an integral contribution to the elaborate program of craniofacial development [46]. Disruption of Shh signaling or platelet-derived growth factor (Pdgf) pathways causes craniofacial abnormalities, including cleft palate [9]. miR-140 negatively regulates Pdgf signaling during palatal development and provides a mechanism for disruption of Pdgf signaling causing palatal clefting. MiR-140 loss of function elevates Pdgfra protein levels, alters palatal shape and causes NCCs to accumulate around the optic stalk, a source of the ligand Pdgfa [47]. Mir-140 disconnects palatal precursor cell migration from Pdgfra signaling [47]. miR-140 modulates Pdgfra-mediated attraction of cranial NCCs to the oral ectoderm, where crest-derived signals are necessary for oral ectodermal gene expression. These results suggest that the conserved regulatory interactions of miR-140 and $p d g$ fra define a mechanism of palatogenesis, and they provide candidate genes for cleft palate.
The TGF- $\beta$ signaling pathway mediated by Smad 2 and Snail is also essential for normal palate development [48, 49]. Molecular interactions exist between miR-200b and TGF- $\beta$-mediated Smad2, Snail and E-cadherin during palatogenesis [50]. miR-200b (1) modulates the expression of E-cadherin, apoptosis and proliferation in the midline epithelial seam region by regulating Smad 2 and Snail, implying an important cellular control mechanism in the precise morphogenesis of the secondary palate; (2) affects migration and palatal fusion through regulation of the Zeb family, Zeb1 and Zeb2, of zinc finger transcription factors [50, 51], and (3) induces E-cadherin expression and reduces Zeb1 and Zeb2 expression [52, 53].

\section{MicroRNAs in Cardiac NCC Patterning}

Dicer and miRNAs are essential for NCC survival, migration and patterning in craniofacial and cardiovascular development $[10,54]$. Targeted deletion of Dicer in NCCs leads to severe craniofacial and cardiovascular defects, which are similar to human congenital neuro-craniofacial-cardiac defects [55]. Dicer loss of function is at least in part mediated by miR-21 and miR-181a, which in turn repress the protein level of Sprouty2, an inhibitor of Erk1/2 signaling [55].

Studies suggest that the NC gives rise to cells that will be part of the cardiovascular system [56]. Cardiac NCCs in the caudal pharynx support development of the persisting aortic arch arteries into the great arteries of the thorax and form their smooth muscle tunics. Mutants of DGCR8, a double-stranded RNA-binding protein that interacts with the RNase III enzyme Drosha and forms a micro-complex in the nucleus to process primary microRNA (pri-miRNA) into precursor miRNA (pre-miRNA) $[57,58]$, display a wide spectrum of malformations, such as persistent truncus arteriosus and ventricular septal defect. Loss of Dgcr8 causes a significant portion of cardiac NCCs to undergo apoptosis, decreasing the pool of progenitors required for cardiac OFT (outflow tract) remodeling, thus suggesting a new role of Dgcr8 in controlling cardiac NCC survival during cardiovascular morphogenesis [59].

\section{Conclusion, Challenges and Future Directions}

Neurocristopathy refers to a diverse class of pathologies that may arise from defects in the development of tissues containing cells derived from the embryonic NCC lineage [60]. Examples (reviewed in [61]) include, but are not restricted to: Waardenburg syndrome, Hirschsprung 
Table 1. The functions of miRNAs during different stages of neural crest specification

a miRNAS during NC specification

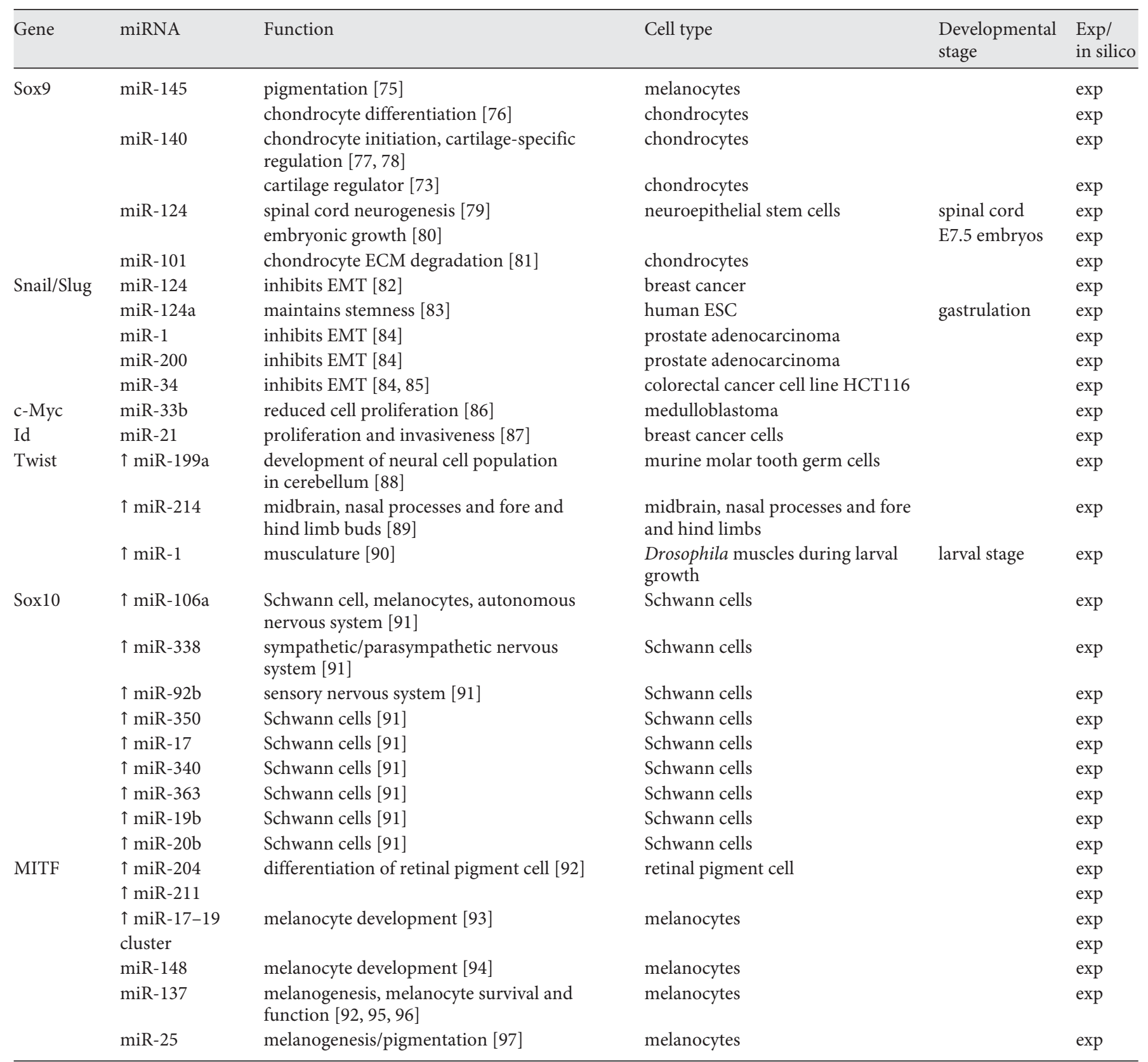

The miRNAs negatively regulate the genes necessary for NC specification, except in case of arrows where the gene products down- or upregulate the miRNA expressions. ECM = Extracellular matrix; Exp = experimental. 
Table 1 (continued)

b miRNAS affecting and affected by NC-inducing signals

\begin{tabular}{|c|c|c|c|c|c|}
\hline $\begin{array}{l}\text { Inducing } \\
\text { signals }\end{array}$ & miRNA & Function & Cell type & $\begin{array}{l}\text { Developmental } \\
\text { stage }\end{array}$ & $\begin{array}{l}\text { Exp/ } \\
\text { in silico }\end{array}$ \\
\hline \multirow{3}{*}{$\begin{array}{l}\text { BMP } \\
\text { signaling }\end{array}$} & miR-26a & inhibition of Smad1/4 [98] & skeletal muscle & & $\exp$ \\
\hline & & $\begin{array}{l}\text { skeletal muscle differentiation and } \\
\text { regeneration }[98]\end{array}$ & skeletal muscle & & $\exp$ \\
\hline & $\downarrow \mathrm{miR}-320-367$ & inhibition of type II BMP receptors [98] & skeletal muscle & & $\exp$ \\
\hline \multirow[t]{2}{*}{ Wnt } & $\operatorname{miR}-142-3 p$ & osteoblast differentiation [99] & osteoblast & & $\exp$ \\
\hline & $\operatorname{miR}-452$ & EMT $[100]$ & NCC & first pharyngeal arch & $\exp$ \\
\hline \multirow[t]{2}{*}{ FGF } & Dgcr8 KO & decreases ERK/FGF signaling [59] & $\begin{array}{l}\text { cardiac and skeletal muscle } \\
\text { precursor cells }\end{array}$ & & $\exp$ \\
\hline & & cardiovascular morphogenesis [59] & $\begin{array}{l}\text { cardiac and skeletal muscle } \\
\text { precursor cells }\end{array}$ & & $\exp$ \\
\hline
\end{tabular}

The miRNAs negatively regulate the NC-inducing signals except in the case of arrows, where the inducing signals are involved in down- or upregulating the expressions of these miRNAs. Exp = Experimental.

c miRNAS affecting neural plate border specifier genes

\begin{tabular}{|c|c|c|c|c|c|}
\hline Gene & miRNAs & Function & Cell type & $\begin{array}{l}\text { Developmental } \\
\text { stage }\end{array}$ & $\begin{array}{l}\text { Exp/ } \\
\text { in silico }\end{array}$ \\
\hline Msx1/2 & miR-181a & osteoblastic differentiation [101] & osteoblasts & & $\exp$ \\
\hline \multirow[t]{2}{*}{ Pax3 } & miR-128a & regulate muscle cell differentiation [102] & muscle cells & & $\exp$ \\
\hline & miR-206 & regulate myogenesis [103] & muscle cells & & $\exp$ \\
\hline Zic 1 & miR-101 & deregulation of $\beta$-catenin [104] & human fibroblasts & & $\exp$ \\
\hline
\end{tabular}

These miRNAs negatively regulate the neural plate border specifier genes. Exp = Experimental.

d miRNAS regulating epigenetic targets

\begin{tabular}{|c|c|c|c|c|c|c|}
\hline Targets & miRNA & Activation or repression & Epigenetic regulation & Cell type & $\begin{array}{l}\text { Dev } \\
\text { stage }\end{array}$ & $\begin{array}{l}\text { Exp/ } \\
\text { in silico }\end{array}$ \\
\hline HDAC4 & miR-1 & repression [105] & CpG methylation & hepatocarcinoma cell & & $\exp$ \\
\hline DNMT3A/B & $\operatorname{miR}-29$ & repression [107] & & lung cancer cells & & $\exp$ \\
\hline $\mathrm{EZH} 2$ & miR-101 & repression [108] & & lung cancer cells & & $\exp$ \\
\hline p300, MeCp2 & $\operatorname{miR}-132$ & activation [109] & $\begin{array}{l}\text { CpG methylation } \\
\text { histone modification }\end{array}$ & cultured rat neurons & & $\exp$ \\
\hline KDM6B & miR-138 & repression [45] & histone modification & NCSCs & E9.5 & $\exp$ \\
\hline DNMT1, 3B & miR-148a & repression [110] & CpG methylation & human breast cancer cells & & $\exp$ \\
\hline KDM6B & miR-148a & repression [45] & histone modification & NCSCs & E9.5 & $\exp$ \\
\hline DNMT1 & $\operatorname{miR}-152$ & repression [110] & CpG methylation & human breast cancer cells & & $\exp$ \\
\hline KDM6B & miR-185 & repression [45] & histone modification & NCSCs & E9.5 & $\exp$ \\
\hline KDM6B & miR-339-5p & repression [45] & histone modification & NCSCs & E9.5 & $\exp$ \\
\hline
\end{tabular}

The expression of epigenetic targets such as HDAC1, HDAC4, EZH2, p300, MeCp2, DNMT1, 3A/3B and KDM6B is regulated by miRNAs. Dev $=$ Developmental; Exp $=$ Experimental. 
disease, piebaldism, congenital central hypoventilation syndrome, pheochromocytoma, paraganglioma, Merkel cell carcinoma, multiple endocrine neoplasia, neurofibromatosis type I, CHARGE syndrome (Coloboma of the eye, Heart defects, Atresia of the nasal choanae, Retardation of growth and/or development, Genital and/or urinary abnormalities, and Ear abnormalities and deafness), familial dysautonomia, DiGeorge syndrome, AxenfeldRieger syndrome, Goldenhar syndrome (hemifacial microsomia), craniofrontonasal syndrome, Noonan syndrome, LEOPARD syndrome, cardiofaciocutaneous syndrome and Costello syndrome (congenital melanocytic nevus, melanoma and certain congenital heart defects of the outflow tract). Understanding the transcriptional, epigenetic and miRNA-mediated regulation of NC induction and specification during delamination, EMT and differentiation of $\mathrm{NC}$ will illuminate development of $\mathrm{NC}$ cells and shed light on pathways associated with neurocristopathies mentioned above.

Furthermore, knowledge of miRNA profiles during NCC differentiation into distinct lineages, in combination with miRNA profiles of differentiated induced pluripotent stem cells (iPSCs) obtained by introduction of Oct4, Sox2, Klf4/Lin28 and c-Myc/Nanog (OSKM) [58] into fibroblasts obtained from patients introduces the possibility of producing adult NCSCs for regenerative purposes [62] for the following reasons: (1) isolated and cultivated epidermal NCSCs have resulted in recovery of function after experimental spinal cord injury in animals that received these cell grafts $[63,64]$, in sharp contrast to tumorigenesis observed after injection of in vitro expanded NCSCs isolated from adult bone marrow [65]; (2) transplanted epidermal NCSCs do not show signs of tumor formation; (3) adult NCSCs have shown promise for the treatment of several diseases requiring regeneration of multiple cell types $[66,67]$, and (4) NCSCs are extraordinarily plastic and are present in the adult organism. The downside in using these epidermal NCSCs is that they are multipotent, not pluripotent because (1) NCSCs express embryonic stem cell (ESC) markers, such as Oct4, Lin28, Sox2, Nanog, SSEA-1, SSEA-3, SSEA-4, TRA-1-60 and TRA-1-81 at much lower levels than ESCs; (2) NCSCs do not form teratomas as a consequence of transplantation into immunodeficient mice $[68,69]$, which casts doubt on their potentially pluripotent status, and (3) adult NCSCs do not give rise to cells of all three germ layers. These hurdles may be overcome by replacing OSKM [70] with appropriate miRNAs (miR-290/302 seed family) to induce the pluripotent state $[71,72]$ and improving reprogramming efficiency of adult NCSCs by either blocking barrier miRNAs or introducing helper miRNAs. Replacing Yamanaka factors (OSKM) with miRNAs to create iPSCs could be a major advance in stem cell biology and regenerative medicine. Recent evidence suggests that miRNAs can be regulated epigenetically $[45,73,74]$. In the future, it is envisaged that epigenetic modulation of miRNA could replace the direct use of miRNA for creation of iPSCs from epidermal NCSCs and subsequently for therapeutic purposes.

\section{Acknowledgements}

I apologize to those whose work I could not cite due to space limitations. This work was supported by funding from the State of Illinois Excellence in Academic Medicine award, the Spastic Paralysis Research Foundation of Illinois-Eastern Iowa, District of Kiwanis, the Spina Bifida Association and Lurie Children's Hospital of Chicago Research Center Pilot Grant. Thanks are due to Ms. Peggy M. Murphy for reading the manuscript and suggesting changes.

\section{References}

1 Slonim AD, Pollack MM (ed): Pediatric Critical Care Medicine. Philadelphia, PA, Lippincott Williams and Wilkins, 2006, p 320.

2 Gilbert SF: The neural crest; in Gilbert SF: Developmental Biology, ed 6. Sunderland, MA, Sinauer Associates, 2000. http://www.ncbi. nlm.nih.gov/books/NBK10065/.

3 Copp AJ, Greene ND, Murdoch JN: The genetic basis of mammalian neurulation. Nat Rev Genet 2003;4:784-793.

4 Shakhova O, Sommer L: Neural Crest-Derived Stem Cells. The Stem Cell Research Community, StemBook, 2010, DOI: 10.3824/ stembook.3821.3851.3821.
-5 Bronner ME, LeDouarin NM: Development and evolution of the neural crest: an overview. Dev Biol 2012;366:2-9.

-6 Bronner ME, LaBonne C: Preface: the neural crest - from stem cell formation to migration and differentiation. Dev Biol 2012;366:1.

7 Ambros VG: MicroRNAs and developmental timing. Curr Opin Genet Dev 2011;21:511517.

$\$ 8$ Li Z, Rana TM: Molecular mechanisms of RNA-triggered gene silencing machineries. Acc Chem Res 2012;45:1122-1131.

-9 Eberhart JK, He X, Swartz ME, Yan YL, Song $\mathrm{H}$, Boling TC, Kunerth AK, Walker MB, Kim- mel CB, Postlethwait JH: MicroRNA Mirn140 modulates Pdgf signaling during palatogenesis. Nat Genet 2008;40:290-298.

10 Cordes KR, Srivastava D: Micro-RNA regulation of cardiovascular development. Circ Res 2009; 104:724-732.

11 Subramanyam D, Blelloch R: From microRNAs to targets: pathway discovery in cell fate transitions. Curr Opin Genet Dev 2011;21: 498-503.

12 Pasquinelli AE: MicroRNAs and their targets: recognition, regulation and an emerging reciprocal relationship. Nat Rev Genet 2012;13: 271-282.
Transcriptional and Epigenetic Regulation of NC Induction
Dev Neurosci 2013;35:361-372 DOI: $10.1159 / 000354749$ 
13 Lawson A, Anderson H, Schoenwolf GC: Cellular mechanisms of neural fold formation and morphogenesis in the chick embryo. Anat Rec 2001;262:153-168.

14 Weinstein DC, Hemmati-Brivanlou A: Neural induction. Annu Rev Cell Dev Biol 1999; 15:411-433.

15 Milet C, Monsoro-Burq AH: Neural crest induction at the neural plate border in vertebrates. Dev Biol 2012;366:22-33.

16 Milet C, Monsoro-Burq AH: Embryonic stem cell strategies to explore neural crest development in human embryos. Dev Biol 2012;366: 96-99.

17 Sato T, Sasai N, Sasai Y: Neural crest determination by co-activation of Pax3 and Zic1 genes in Xenopus ectoderm. Development 2005; 132:2355-2363.

18 Betancur P, Bronner-Fraser M, Sauka-Spengler T: Assembling neural crest regulatory circuits into a gene regulatory network. Ann Rev Cell Dev Biol 2010;26:581-603.

19 Duband JL: Diversity in the molecular and cellular strategies of epithelium-to-mesenchyme transitions: insights from the neural crest. Cell Adh Migr 2010;4:458-482.

20 Burstyn-Cohen T, Stanleigh J, Sela-Donenfeld D, Kalcheim C: Canonical Wnt activity regulates trunk neural crest delamination linking $\mathrm{BMP} /$ noggin signaling with G1/S transition. Development 2004; 131:53275339.

-21 Liu Y, Helms AW, Johnson JE: Distinct activities of Msx1 and Msx3 in dorsal neural tube development. Development 2004;131: 1017-1028.

22 Cheung M, Chaboissier MC, Mynett A, Hirst E, Schedl A, Briscoe J: The transcriptional control of trunk neural crest induction, survival, and delamination. Dev Cell 2005;8:179192.

-23 Chalpe AJ, Prasad M, Henke AJ, Paulson AF: Regulation of cadherin expression in the chicken neural crest by the Wnt $/ \beta$-catenin signaling pathway. Cell Adh Migr 2010;4: 431-438.

24 Liu JP, Jessell TM: A role for rhoB in the delamination of neural crest cells from the dorsal neural tube. Development 1998;125:50555067.

25 Sela-Donenfeld D, Kalcheim C: Regulation of the onset of neural crest migration by coordinated activity of BMP4 and Noggin in the dorsal neural tube. Development 1999;126: 4749-4762.

26 Sela-Donenfeld D, Kalcheim C: Inhibition of noggin expression in the dorsal neural tube by somitogenesis: mechanisms for coordinating the timing of neural crest emigration. Development 2000;127:4845-4854.

27 Thiery JP, Acloque H, Huang RY, Nieto MA Epithelial-mesenchymal transitions in development and disease. Cell 2009;139:871890.

28 Thiery JP, Sleeman JP: Complex networks orchestrate epithelial-mesenchymal transitions. Nat Rev Mol Cell Biol 2006;7:131-142.
29 Lim J, Thiery JP: Epithelial-mesenchymal transitions: insights from development. Development 2012;139:3471-3486.

-30 Taneyhill LA, Coles EG, Bronner-Fraser M: Snail2 directly represses cadherin6B during epithelial-to-mesenchymal transitions of the neural crest. Development 2007;134:14811490.

31 Hatta K, Takagi S, Fujisawa H, Takeichi M: Spatial and temporal expression pattern of $\mathrm{N}$ cadherin cell adhesion molecules correlated with morphogenetic processes of chicken embryos. Dev Biol 1987;120:215-227.

- 32 Mayor R, Carmona-Fontaine C: Keeping in touch with contact inhibition of locomotion. Trends Cell Biol 2010;20:319-328.

33 Theveneau E, Mayor R: Neural crest delamination and migration: from epithelium-tomesenchyme transition to collective cell migration. Dev Biol 2012;366:34-54.

34 Lefebvre V, Huang W, Harley VR, Goodfellow PN, de Crombrugghe B: SOX9 is a potent activator of the chondrocyte-specific enhancer of the Proal (II) collagen gene. Mol Cell Biol 1997; 17:2336-2346.

-35 Kelsh RN: Sorting out Sox10 functions in neural crest development. Bioessays 2006;28: 788-798.

36 Potterf SB, Mollaaghababa R, Hou L, Southard-Smith EM, Hornyak TJ, Arnheiter $\mathrm{H}, \mathrm{Pa}$ van WJ: Analysis of SOX10 function in neural crest-derived melanocyte development: SOX10-dependent transcriptional control of dopachrome tautomerase. Dev Biol 2001;237: 245-257.

- 37 Huber WE, Price ER, Widlund HR, Du J, Davis IJ, Wegner M, Fisher DE: A tissue-restricted cAMP transcriptional response: SOX10 modulates alpha-melanocyte-stimulating hormone-triggered expression of microphthalmia-associated transcription factor in melanocytes. J Biol Chem 2003;278:4522445230.

38 Kim J, Lo L, Dormand E, Anderson DJ: SOX10 maintains multipotency and inhibits neuronal differentiation of neural crest stem cells. Neuron 2003;38:17-31.

39 Lang D, Chen F, Milewski R, Li J, Lu MM, Epstein JA: Pax3 is required for enteric ganglia formation and functions with Sox10 to modulate expression of c-Ret. J Clin Invest 2000;106:963-971.

40 Lang D, Epstein JA: Sox10 and Pax3 physically interact to mediate activation of a conserved c-RET enhancer. Hum Mol Genet 2003;12:937-945

41 Stolt CC, Rehberg S, Ader M, Lommes P, Riethmacher D, Schachner M, Bartsch U, Wegner M: Terminal differentiation of myelin forming oligodendrocytes depends on the transcription factor Sox10. Genes Dev 2002; $16: 165-170$

-42 Schlierf B, Werner T, Glaser G, Wegner M: Expression of connexin47 in oligodendrocytes is regulated by the Sox 10 transcription factor. J Mol Biol 2006;361:11-21.
43 Sieber-Blum M: Epidermal neural crest stem cells and their use in mouse models of spinal cord injury. Brain Res Bull 2010;83:189-193.

44 Strobl-Mazzulla PH, Marini M, Buzzi A: Epigenetic landscape and miRNA involvement during neural crest development. Dev Dyn 2012;241:1849-1856.

-45 Ichi S, Costa FF, Bischof JM, Nakazaki H, Shen YW, Boshnjaku V, Sharma S, ManiaFarnell B, McLone DG, Tomita T, Soares MB, Mayanil CS: Folic acid remodels chromatin on Hes1 and Neurog2 promoters during caudal neural tube development. J Biol Chem 2010;285:36922-36932.

46 Pan A, Chang L, Nguyen A, James AW: A review of hedgehog signaling in cranial bone development. Front Physiol 2013;4:61.

47 Clouthier DE, Gray J, Artinger KB: Micromanaging palate development. Perspect Speech Sci Orofac Disord 2008; 18:62-72.

- 48 Martínez-Alvarez C, Blanco MJ, Pérez R, Rabadán MA, Aparicio M, Resel E, Martínez T, Nieto MA: Snail family members and cell survival in physiological and pathological cleft palates. Dev Biol 2004;265:207-218.

49 Nawshad A, Medici D, Liu CC, Hay ED: TGFbeta3 inhibits E-cadherin gene expression in palate medial-edge epithelial cells through a Smad2-Smad4-LEF1 transcription complex. J Cell Sci 2007;120:1646-1653.

50 Shin JO, Lee JM, Cho KW, Kwak S, Kwon HJ, Lee MJ, Cho SW, Kim KS, Jung HS: MiR-200b is involved in Tgf- $\beta$ signaling to regulate mammalian palate development. Histochem Cell Biol 2012;137:67-78.

-51 Shin JO, Nakagawa E, Kim EJ, Cho KW, Lee JM, Cho SW, Jung HS: miR-200b regulates cell migration via Zeb family during mouse palate development. Histochem Cell Biol 2012;137:459-470.

52 Gregory PA, Bert AG, Paterson EL, Barry SC, Tsykin A, Farshid G, Vadas MA, KhewGoodall Y, Goodall GJ: The miR-200 family and miR-205 regulate epithelial to mesenchymal transition by targeting ZEB1 and SIP1. Nat Cell Biol 2008;10:593-601.

53 Park SM, Gaur AB, Lengyel E, Peter ME: The miR-200 family determines the epithelial phenotype of cancer cells by targeting the Ecadherin repressors ZEB1 and ZEB2. Genes Dev 2008;22:894-907.

54 Small EM, Olson EN: Pervasive roles of microRNAs in cardiovascular biology. Nature 2011;469:336-342.

55 Huang ZP, Chen JF, Regan JN, Maguire CT, Tang RH, Dong XR, Majesky MW, Wang DZ: Loss of microRNAs in neural crest leads to cardiovascular syndromes resembling human congenital heart defects. Arterioscler Thromb Vasc Biol 2010;30:2575-2586.

56 Kirby ML, Hutson MR: Factors controlling cardiac neural crest cell migration. Cell Adh Migr 2010;4:609-621.

-57 Gregory RI, Yan KP, Amuthan G, Chendrimada T, Doratotaj B, Cooch N, Shiekhattar R: The microprocessor complex mediates the genesis of microRNAs. Nature 2004;432:235-240. 
58 Han J, Lee Y, Yeom KH, Kim YK, Jin H, Kim VN: The Drosha-DGCR8 complex in primary microRNA processing. Genes Dev 2004; 18 : 3016-3027.

-59 Chapnik E, Sasson V, Blelloch R, Hornstein E: Dgcr8 controls neural crest cells survival in cardiovascular development. Dev Biol 2012; 362:50-56.

60 Bolande RP: The neurocristopathies: a unifying concept of disease arising in neural crest maldevelopment. Hum Pathol 1974;5:409429.

61 Bolande RP: Neurocristopathy: its growth and development in 20 years. Pediatr Pathol Lab Med 1997;17:1-25.

- 62 Kaltschmidt B, Kaltschmidt C, Widera D: Adult craniofacial stem cells: sources and relation to the neural crest. Stem Cell Rev 2012; 8:658-671.

63 Stanchina L, Baral V, Robert F, Pingault V, Lemort N, Pachnis V, Goossens M, Bondurand $\mathrm{N}$ : Interactions between Sox10, Edn3 and Ednrb during enteric nervous system and melanocyte development. Dev Biol 2006;295: 232-249.

$64 \mathrm{Hu}$ YF, Gourab K, Wells C, Clewes O, Schmit BD, Sieber-Blum M: Epidermal neural crest stem cell (EPI-NCSC)-mediated recovery of sensory function in a mouse model of spinal cord injury. Stem Cell Rev 2010;6:186-198.

-65 Wislet-Gendebien S, Poulet C, Neirinckx V, Hennuy B, Swingland JT, Laudet E, Sommer L, Shakova O, Bours V, Rogister B: In vivo tumorigenesis was observed after injection of in vitro expanded neural crest stem cells isolated from adult bone marrow. PLoS One 2012;7:e46425.

66 King-Robson J: Encouraging regeneration in the central nervous system: is there a role for olfactory ensheathing cells? Neurosci Res 2010;69:263-275.

-67 Nivet E, Vignes M, Girard SD, Pierrisnard C, Baril N, Devèze A, Magnan J, Lanté F, Khrestchatisky M, Féron F, Roman FS: Engraftment of human nasal olfactory stem cells restores neuroplasticity in mice with hippocampal lesions. J Clin Invest 2011;121:2808-2820.

-68 Hauser S, Widera D, Qunneis F, Müller J, Zander C, Greiner J, Strauss C, Lüningschrör P, Heimann P, Schwarze H, Ebmeyer J, Sudhoff H, Araúzo-Bravo MJ, Greber B, Zaehres H, Schöler H, Kaltschmidt C, Kaltschmidt B: Isolation of novel multipotent neural crestderived stem cells from adult human inferior turbinate. Stem Cells Dev 2012;21:742-756.

-69 Sieber-Blum M, Hu Y: Epidermal neural crest stem cells (EPI-NCSC) and pluripotency. Stem Cell Rev 2008;4:256-260.

70 Takahashi K, Yamanaka S: Induction of pluripotent stem cells from mouse embryonic and adult fibroblast cultures by defined factors. Cell 2006;126:663-676.
Lüningschrör P, Stöcker B, Kaltschmidt B, Kaltschmidt C: miR-290 cluster modulates pluripotency by repressing canonical NF- $\kappa \mathrm{B}$ signaling. Stem Cells 2012;30:655-664.

72 Yang CS, Rana TM: Learning the molecular mechanisms of the reprogramming factors: let's start from microRNAs. Mol Biosyst 2013; 9:10-17.

73 Mazar J, Khaitan D, DeBlasio D, Zhong C, Govindarajan SS, Kopanathi S, Zhang S, Ray A, Perera RJ: Epigenetic regulation of microRNA genes and the role of miR-34b in cell invasion and motility in human melanoma. PLoS One 2011;6:e24922.

74 Perera RJ, Ray A: Epigenetic regulation of miRNA genes and their role in human melanomas. Epigenomics 2012;4:81-90.

75 Dynoodt P, Mestdagh P, Van Peer G, Vandesompele J, Goossens K, Peelman LJ, Geusens B, Speeckaert RM, Lambert JL, Van Gele MJ: Identification of miR-145 as a key regulator of the pigmentary process. J Invest Dermatol 2013;133:201-209.

76 Yang B, Guo H, Zhang Y, Ying D, Dong S: MicroRNA-145 regulates chondrogenic differentiation of mesenchymal stem cells by targeting Sox9. PLoS One 2012;6:e21679.

77 Yamashita S, Miyaki S, Kato Y, Yokoyama S, Sato T, Barrionuevo F, Akiyama H, Scherer G, Takada S, Asahara H: L-Sox5 and Sox6 proteins enhance chondrogenic miR-140 microRNA expression by strengthening dimeric Sox9 activity. J Biol Chem 2012;287:2220622215.

78 Nakamura Y, He X, Kato H, Wakitani S, Kobayashi $\mathrm{T}$, Watanabe $\mathrm{S}$, Iida $\mathrm{A}$, Tahara $\mathrm{H}$, Warman ML, Watanapokasin R, Postlethwait $\mathrm{JH}$ : Sox9 is upstream of microRNA-140 in cartilage. Appl Biochem Biotechnol 2012;166: 64-71.

79 Farrell BC, Power EM, McDermott KW: Developmentally regulated expression of Sox 9 and microRNAs 124, 128 and 23 in neuroepithelial stem cells in the developing spinal cord. Int J Dev Neurosci 2011;29:31-36.

80 Grandjean V, Gounon P, Wagner N, Martin L, Wagner KD, Bernex F, Cuzin F, Rassoulzadegan M: The miR-124-Sox9 paramutation: RNA-mediated epigenetic control of embryonic and adult growth. Development 2009; 136:3647-3655

81 Dai L, Zhang X, Hu X, Zhou C, Ao Y: Silencing of microRNA-101 prevents IL-1 $\beta$ induced extracellular matrix degradation in chondrocytes. Arthritis Res Ther 2012; 14:R268.

82 Lee MR, Kim JS, Kim KS: miR-124a is important for migratory cell fate transition during gastrulation of human embryonic stem cells. Stem Cells 2010;28:1550-1559.

83 Liang YJ, Wang QY, Zhou CX, Yin QQ, He M, Yu XT, Cao DX, Chen GQ, He JR, Zhao Q: MiR-124 targets Slug to regulate epithelialmesenchymal transition and metastasis of breast cancer. Carcinogenesis 2013;34:713722 .
84 Liu YN, Yin JJ, Abou-Kheir W, Hynes PG, Casey OM, Fang L, Yi M, Stephens RM, Seng V, Sheppard-Tillman H, Martin P, Kelly K: MiR-1 and miR-200 inhibit EMT via Slug-dependent and tumorigenesis via Slug-independent mechanisms. Oncogene 2013;32:296306.

-85 Siemens H, Jackstadt R, Hünten S, Kaller M, Menssen A, Götz U, Hermeking H: miR-34 and SNAIL form a double-negative feedback loop to regulate epithelial-mesenchymal transitions. Cell Cycle 2011;10:4256-4271.

86 Takwi AA, Li Y, Becker Buscaglia LE, Zhang J, Choudhury S, Park AK, Liu M, Young KH, Park WY, Martin RC, Li Y: A statin-regulated microRNA represses human c-Myc expression and function. EMBO Mol Med 2012;4: 896-909.

87 Huang TH, Wu F, Loeb GB, Hsu R, Heidersbach A, Brincat A, Horiuchi D, Lebbink RJ, Mo YY, Goga A, McManus MT: Up-regulation of miR-21 by HER2/neu signaling promotes cell invasion. J Biol Chem 2009;284: 18515-18524.

88 Sehic A, Risnes S, Khuu C, Khan QE, Osmundsen $\mathrm{H}$ : Effects of in vivo transfection with anti-miR-214 on gene expression in murine molar tooth germ. Physiol Genomics 2011;43:488-498.

89 Lee YB, Bantounas I, Lee DY, Phylactou L, Caldwell MA, Uney JB: Twist-1 regulates the miR-199a/214 cluster during development. Nucleic Acids Res 2009;37:123-128.

-90 Sokol NS, Ambros V: Mesodermally expressed Drosophila microRNA-1 is regulated by Twist and is required in muscles during larval growth. Genes Dev 2005;19:2343-2354.

-91 Gokey NG, Srinivasan R, Lopez-Anido C, Krueger C, Svaren J: Developmental regulation of microRNA expression in Schwann cells. Mol Cell Biol 2012;32:558-568.

-92 Adijanto J, Castorino JJ, Wang ZX, Maminishkis A, Grunwald GB, Philp NJ: Microphthalmia-associated transcription factor (MITF) promotes differentiation of human retinal pigment epithelium (RPE) by regulating microRNAs-204/211 expression. J Biol Chem 2012;287:20491-20503.

93 Levy C, Khaled M, Robinson KC, Veguilla RA, Chen PH, Yokoyama S, Makino E, Lu J, Larue L, Beermann F, Chin L, Bosenberg M, Song JS, Fisher DE: Lineage-specific transcriptional regulation of DICER by MITF in melanocytes. Cell 2010;141:994-1005.

94 Haflidadóttir BS, Bergsteinsdóttir K, Praetorius C, Steingrímsson E: miR-148 regulates Mitf in melanoma cells. PLoS One 2010; 5:e11574.

95 Bemis LT, Chen R, Amato CM, et al: MicroRNA-137 targets microphthalmia-associated transcription factor in melanoma cell lines. Cancer Res 2008;68:1362-1368. 
96 Goswami S, Tarapore RS, Teslaa JJ, Grinblat Y, Setaluri V, Spiegelman VS: MicroRNA340-mediated degradation of microphthalmia-associated transcription factor mRNA is inhibited by the coding region determinant-binding protein. J Biol Chem 2010; 285:20532-20540.

97 Zhu Z, He J, Jia X, Jiang J, Bai R, Yu X, Lv L, Fan R, He X, Geng J, You R, Dong Y, Qiao $\mathrm{D}$, Lee KB, Smith GW, Dong C: MicroRNA-25 functions in regulation of pigmentation by targeting the transcription factor MITF in Alpaca (Lama pacos) skin melanocytes. Domest Anim Endocrinol 2010;38: 200-209.

-98 Dey BK, Gagan J, Yan Z, Dutta A: miR-26a is required for skeletal muscle differentiation and regeneration in mice. Genes Dev 2012;26:2180-2191.

-99 Hu W, Ye Y, Zhang W, Wang J, Chen A, Guo F: miR-142-3p promotes osteoblast differentiation by modulating Wnt signaling. Mol Med Rep 2013;7:689-693.

100 Sheehy NT, Cordes KR, White MP, Ivey $\mathrm{KN}$, Srivastava D: The neural crest-enriched microRNA miR-452 regulates epithelial-mesenchymal signaling in the first pharyngeal arch. Development 2010;137: 4307-4316.
101 Okamoto H, Matsumi Y, Hoshikawa Y, Takubo K, Ryoke K, Shiota G: Involvement of microRNAs in regulation of osteoblastic differentiation in mouse induced pluripotent stem cells. PLoS One 2012; 7:e43800.

102 Motohashi N, Alexander MS, Casar JC, Kunkel LM: Identification of a novel microRNA that regulates the proliferation and differentiation in muscle side population cells. Stem Cells Dev 2012;21:3031-3043.

103 Goljanek-Whysall K, Sweetman D, Abu-Elmagd M, Chapnik E, Dalmay T, Hornstein E, Münsterberg A: MicroRNA regulation of the paired-box transcription factor Pax3 confers robustness to developmental timing of myogenesis. Proc Natl Acad Sci USA 2011;108:11936-11941.

104 Mosakhani N, Guled M, Lahti L, Borze I, Forsman M, Pääkkönen V, Ryhänen J, Knuutila S: Unique microRNA profile in Dupuytren's contracture supports deregulation of $\beta$-catenin pathway. Mod $\mathrm{Pa}$ thol 2010;23:1544-1552.

105 Datta J, Kutay H, Nasser MW, Nuovo GJ, Wang B, Majumder S, Liu CG, Volinia S, Croce CM, Schmittgen TD, Ghoshal K, Jacob ST: Methylation mediated silencing of microRNA-1 gene and its role in hepatocellular carcinogenesis. Cancer Res 2008;68: 5049-5058.

106 Wong CF, Tellam RL: MicroRNA-26a targets the histone methyltransferase enhancer of zeste homolog 2 during myogenesis. J Biol Chem 2008;283:9836-9843.
07 Fabbri M, Garzon R, Cimmino A, Liu Z, Zanesi N, Callegari E, Liu S, Alder H, Costinean S, Fernandez-Cymering C, Volinia S, Guler G, Morrison CD, Chan KK, Marcucci G, Calin GA, Huebner K, Croce CM: MicroRNA-29 family reverts aberrant methylation in lung cancer by targeting DNA methyltransferases $3 \mathrm{a}$ and $3 \mathrm{~b}$. Proc Natl Acad Sci USA 2007;104:15805-15810.

08 Cao P, Deng Z, Wan M, Huang W, Cramer SD, Xu J, Lei M, Sui G: MicroRNA-101 negatively regulates Ezh2 and its expression is modulated by androgen receptor and HIF1alpha/HIF-1beta. Mol Cancer 2010;9:108.

109 Klein ME, Lioy DT, Ma L, Impey S, Mandel G, Goodman RH: Homeostatic regulation of MeCP2 expression by a CREB-induced microRNA. Nat Neurosci 2007;10:15131514.

110 Lehmann U, Hasemeier B, Christgen M, Müller M, Römermann D, Länger F, Kreipe $\mathrm{H}$ : Epigenetic inactivation of microRNA gene HSA-miR-9-1 in human breast cancer. J Pathol 2008;214:17-24.

111 Noonan EJ, Place RF, Pookot D, Basak S, Whitson JM, Hirata H, Giardina C, Dahiya R: miR-449a targets HDAC-1 and induces growth arrest in prostate cancer. Oncogene 2009;28:1714-1724. 